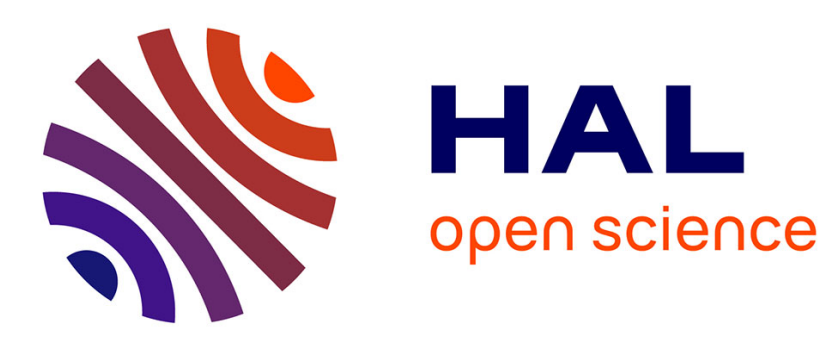

\title{
Domestic Cat Predation on Garden Birds: An Analysis from European Ringing Programmes
}

\author{
Roman Pavisse, Didier Vangeluwe, Philippe Clergeau
}

\section{To cite this version:}

Roman Pavisse, Didier Vangeluwe, Philippe Clergeau. Domestic Cat Predation on Garden Birds: An Analysis from European Ringing Programmes. Ardea, 2019, 107 (1), pp.103. 10.5253/arde.v107i1.a6 . hal-02188701

\section{HAL Id: hal-02188701 \\ https://hal.sorbonne-universite.fr/hal-02188701}

Submitted on 18 Jul 2019

HAL is a multi-disciplinary open access archive for the deposit and dissemination of scientific research documents, whether they are published or not. The documents may come from teaching and research institutions in France or abroad, or from public or private research centers.
L'archive ouverte pluridisciplinaire $\mathbf{H A L}$, est destinée au dépôt et à la diffusion de documents scientifiques de niveau recherche, publiés ou non, émanant des établissements d'enseignement et de recherche français ou étrangers, des laboratoires publics ou privés. 


\title{
Domestic Cat predation on garden birds: an analysis from European ringing programmes
}

\author{
Roman Pavisse $^{1}$, Didier Vangeluwe ${ }^{2} \&$ Philippe Clergeau ${ }^{1, *}$
}

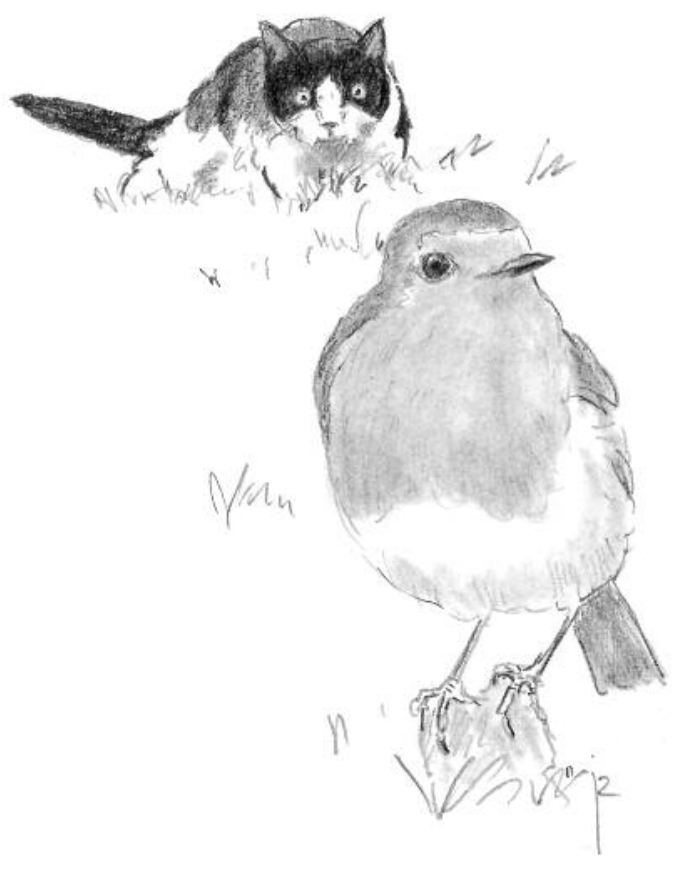

Domestic Cat Felis silvestris catus populations have been increasing since the 1970 s in Western Europe. This increase is particularly notable in human habitats, such as gardens and parks, where Cats have locally become the most abundant carnivore. In urban contexts, understanding Cat behaviour could be important for biodiversity management. In this study, we analysed Cat predation on garden birds, using existing data from ringing programmes in France and Belgium. These types of data permit us to (1) investigate the bird species killed by Cats, (2) analyse changes in the proportion of birds killed by Cats over the years 2000-2015, and (3) compare the causes of bird mortality as reported by observers. The most affected species were passerines, both granivorous and insectivorous (Europian Robin Erithacus rubecula, Dunnock Prunella modularis, Greenfinch Carduelis chloris), who can frequently be found feeding on the ground or visiting feeders in the winter. Perched birds (Chiffchaff Phylloscopus collybita, Blackcap Sylvia atricapilla) were less represented. Ground-dwelling habits were significantly correlated to predation rates. Between 2000 and 2015, Cat-related mortality in garden birds increased by at least $50 \%$, depending on the ringing programme studied, which coincided with an increase in Cat populations. Cat-related mortality is one of the leading causes of death reported by observers (12.8-26.3\% of total dead birds) and occurs at the same order of magnitude as deaths due to collisions with windows. These results underline the need to consider Cats and their potential impacts on urban biodiversity management at garden and urban levels.

Key words: urban biodiversity, pets, passerines, predator, garden birds, Domestic Cat

${ }^{1}$ Muséum National d'Histoire Naturelle, UMR CESCO MNHN/UPMC/CNRS, 43 rue Buffon, 75005 Paris, France;

${ }^{2}$ BeBirds - Bird Ringing for Science and Conservation. Institut Royal des Sciences Naturelles de Belgique, rue Vautier 29, 1000 Bruxelles;

${ }^{*}$ corresponding author (philippe.clergeau@mnhn.fr)

The impact of Domestic Cats Felis silvestris catus, Cat from hereon, on biodiversity and particularly on bird populations, has been documented worldwide (Parmalee 1953, Churcher \& Lawton 1987, Barratt 1997, Loss \& Marra 2017). However, the majority of currently available studies address closed ecosystems, such as small islands (Medina et al. 2011). The impact of Cat populations can be very strong in these cases, even leading to local extinctions of species (Veitch 1985, Dowding \& Murphy 2001, Medway 2004). The impact of Cat populations appears to be less clear in continental ecosystems, especially in North America and Europe. The presence of Cats may significantly impact the number of birds through both predation events (Woods et al. 2003, Winter \& Wallace 2006, Dauphiné \& Cooper 2009) and lower fertility rates linked to the disturbances induced by the presence of these predators (Beckerman et al. 2007, Bonnington et al. 2013). In the United Kingdom, Baker et al. (2008) suggested that Cats have likely been a major cause of mortality for some species of birds.

Today, a tendency exists to enhance biodiversity in towns, favouring the quality of green spaces and species dispersion from peri-urban areas to city parks and gardens. This trend implies changing management strategies resulting in an increase in vertebrate diversity 
and number (Baker \& Harris 2007, Pellissier 2012). As Cats are the main predator in towns and peri-urban landscapes (e.g. Coleman et al. 1997, Lepczyk et al. 2004, Thomas et al. 2012), it is important to assess to what extent Cats impact biodiversity in these habitats. The available studies (e.g. Baker et al. 2005, Woods et al. 2003, Tschanz et al. 2011) show that small mammals, mainly rodents, are the most abundant prey in the diet of Domestic Cats in urban and rural landscapes, but that birds can represent 12 to $24 \%$ of observed prey species.

In Europe, house Cat populations (in contrast to feral Cats) have significantly increased over the past few decades to an estimated 99 million in 2014 (FEDIAF 2014). In France, the number of house Cats has increased since 1970, and doubled between 1990 and 2015 (FACCO 2017). In Belgium, the house Cat population increased by 200,000 between 2008 and 2014 (SPF Economie 2016). The number of feral or stray Cats remains completely unknown.

To assess the impact of Cats on urban bird populations, we focus here on garden bird data from French and Belgian ringing programmes where the causes of death are noted. We wanted to (1) investigate the bird species killed by Domestic Cats, (2) analyse changes in the proportion of birds killed by Cats over time (2000-2015), and (3) compare the causes of bird mortality as reported by observers.

\section{Methods}

To study Domestic Cat predation on garden birds and examine how it has changed over time, we analysed the French and Belgian ring-recovery programme data collected from 2000 to 2015. In these two countries, the rings from birds found dead are returned with a response indicating the probable cause of death including predation by Cats (see below). In two thirds of these cases, information on ringed birds was precisely recorded allowing a quantitative analysis of causes of mortality including the prevalence of Cat predation. Those reporting these dead birds were not only ornithologists but also people who directly observed a cat eat or kill the bird and/or found a whole or partial bird body near their house. The remaining third of returns were without a cause of death.

Only data including birds recovered in France and Belgium were analysed. We assume that the probability of reporting a ringed bird killed by a Cat is the same regardless of the bird species being considered and whether it is ringed. There was no indication that reporting effort varied over the study period (Oliver Dehorter, CRBPO, pers. comm.).
To study Cat predation, we separately analysed three datasets where the causes of death were mentioned (Table 1): (1) The SPOL Mangeoire programme in France (feeder-centred monitoring of local wintering bird populations) is a capture-based monitoring programme that has been operational since 2007. This programme aims to monitor wintering birds visiting bird feeders. This monitoring is focused on specific species and habitats, i.e. garden birds, in environments where observers are numerous and where recovery rates are potentially higher. Data were collected at more than 150 sites across the country between 2007 and 2015. Hereafter, this programme is referred to as Prog1. (2) The STOC capture (temporal monitoring of common birds through capture) protocol is for monitoring common birds in France in generally diverse environments and at the initiative of the ringers (approximately 120 locations monitored between 2000 and 2015), and a great number of protocols are dedicated to specific processes or habitats that display relatively homogeneous sensitivity to predation by Cats. This dataset is not specifically dedicated to garden birds. Hereafter, this programme is referred to as Prog2. (3) All of the Belgian data collection programmes are included in this category. In Belgium, there are no programmes specifically dedicated to species or habitats. Data from Belgium essentially relate to the activity of workgroups that have autonomy in ringing practices. This dataset is also not specifically dedicated to garden birds. Hereafter, this programme is referred to as Prog3 (data also from 2000 to 2015).

We focused on 43 species known to be common in gardens (selected from Hagemeijer \& Blair 1997; Table $1)$. Due to the very large difference in ringing effort between species, we avoided the few species that had less than 10,000 ringed individuals, i.e. Spotted Flycatcher Muscicapa striata, European Serin Serinus serinus, European Crested Tit Lophophanes cristatus, Great Spotted Woodpecker Dendrocopos major and Cirl Bunting Emberiza cirlus.

First, to analyse Cat predation on each of the remaining 38 species, we determined the rate of predation over the entire study period. In agreement with the very variable rate of ring returns depending on the species (Oliver Dehorter, CRBPO, pers. comm.), we have chosen to calculate the predation rate on the total of ringed individuals of a species and not on the total of returns of ringed birds. As a result, the values will be very low. For each programme, we tested the hypothesis that the annual change of the Cat-related death rate for all birds followed a linear model using the $\mathrm{R} v$. 3.2.5 software (R Development Core Team 2016). 
Table 1. The 38 passerine and dove species obtained from the three programmes (Prog1 for wintering birds in French gardens, Prog2 for STOC in France and Prog3 for Belgian data) and category of ground-feeding (1: rarely, 2: sometimes, and 3: frequently on the ground). For each programme the number of ringed birds is listed. Species are ordered according to decreasing predations rate, which is the percentage of ringed birds predated by Cats over all years combined.

\begin{tabular}{|c|c|c|c|c|c|c|}
\hline \multirow[t]{2}{*}{ Species } & \multirow{2}{*}{$\begin{array}{l}\text { Category of } \\
\text { ground- } \\
\text { feeding }\end{array}$} & \multicolumn{4}{|c|}{ Number ringed } & \multirow{2}{*}{$\begin{array}{c}\text { Predation rate } \\
(\% \text { of ringend } \\
\text { birds, } \times 10^{-5} \text { ) }\end{array}$} \\
\hline & & Prog1 & Prog2 & Prog3 & Total & \\
\hline European Greenfinch Chloris chloris & 3 & 43,300 & 32,501 & 185,700 & 261,501 & 56.21 \\
\hline Eurasian Collared Dove Streptopelia decaocto & 2 & 239 & 16,978 & 18,119 & 35,336 & 50.94 \\
\hline House Sparrow Passer domesticus & 3 & 8969 & 72,138 & 54,300 & 135,407 & 48.74 \\
\hline Common Blackbird Turdus merula & 3 & 4479 & 79,311 & 142,140 & 225,930 & 48.24 \\
\hline European Robin Erithacus rubecula & 3 & 3204 & 115,229 & 397,000 & 515,433 & 39.97 \\
\hline European Goldfinch Carduelis carduelis & 3 & 15,941 & 20,747 & 31,552 & 68,240 & 39.57 \\
\hline Dunnock Prunella modularis & 3 & 2042 & 38,790 & 272,500 & 313,332 & 36.38 \\
\hline Eurasian Siskin Spinus spinus & 2 & 17,219 & 11,221 & 134,200 & 162,640 & 35.66 \\
\hline Black Redstart Phoenicurus ochruros & 2 & 178 & 5414 & 6800 & 12,392 & 32.28 \\
\hline Eurasian Blue Tit Cyanistes caeruleus & 1 & 48,179 & 140,223 & 646,500 & 834,902 & 32.10 \\
\hline Eurasian Wren Troglodytes troglodytes & 2 & 595 & 17,645 & 42,280 & 60,520 & 31.39 \\
\hline Great Tit Parus major & 1 & 47,709 & 110,792 & 801,000 & 959,501 & 27.72 \\
\hline Hawfinch Coccothraustes coccothraustes & 2 & 999 & 1591 & 8990 & 11,580 & 25.91 \\
\hline Common Starling Sturnus vulgaris & 3 & 849 & 14,019 & 165,166 & 180,034 & 22.22 \\
\hline Eurasian Bullfinch Pyrrhula pyrrhula & 2 & 391 & 6021 & 7426 & 13,838 & 21.68 \\
\hline Song Thrush Turdus philomelos & 2 & 339 & 42,842 & 133,051 & 176,232 & 20.99 \\
\hline Coal Tit Periparus ater & 1 & 1289 & 11,757 & 73,600 & 86,646 & 17.31 \\
\hline Long-Tailed Tit Aegithalos caudatus & 2 & 1530 & 20,114 & 43,357 & 65,001 & 16.92 \\
\hline Common Redstart Phoenicurus phoenicurus & 2 & 25 & 8184 & 23,400 & 31,609 & 15.82 \\
\hline Eurasian Nuthatch Sitta europaea & 1 & 970 & 2224 & 22,600 & 25,794 & 15.51 \\
\hline Common Chaffinch Fringilla coelebs & 2 & 9986 & 20,556 & 147,350 & 177,892 & 13.49 \\
\hline Eurasian Tree Sparrow Passer montanus & 2 & 1181 & 6585 & 105,300 & 113,066 & 13.28 \\
\hline Eurasian Blackcap Sylvia atricapilla & 1 & 1269 & 352,517 & $1,646,000$ & $1,999,786$ & 12.60 \\
\hline Yellowhammer Emberiza citrinella & 2 & 157 & 4385 & 12,836 & 17,378 & 11.51 \\
\hline Common Swift Apus apus & 1 & 1 & 3155 & 7290 & 10,446 & 9.57 \\
\hline Common Wood Pigeon Columba palumbus & 2 & 16 & 43,699 & 11,200 & 54,915 & 9.11 \\
\hline Barn Swallow Hirundo rustica & 1 & 29 & 213,935 & 276,000 & 489,964 & 8.57 \\
\hline Short-Toed Treecreeper Certhia brachydactyla & 1 & 286 & 3871 & 9031 & 13,188 & 7.58 \\
\hline White Wagtail Motacilla alba & 2 & 21 & 2917 & 63,700 & 66,638 & 7.50 \\
\hline Goldcrest Regulus regulus & 2 & 589 & 12,064 & 82,100 & 94,753 & 7.39 \\
\hline Brambling Fringilla montifringilla & 2 & 4795 & 4438 & 85,662 & 94,895 & 7.38 \\
\hline Marsh Tit Poecile palustris & 2 & 1989 & 4439 & 7900 & 14,328 & 6.99 \\
\hline European Pied Flycatcher Ficedula hypoleuca & 2 & 2 & 14,405 & 46,300 & 60,707 & 6.59 \\
\hline Common Chiffchaff Phylloscopus collybita & 1 & 541 & 124,081 & 328,200 & 452,822 & 6.62 \\
\hline Common Linnet Linaria cannabina & 1 & 25 & 6416 & 122,052 & 128,493 & 5.45 \\
\hline Common House Martin Delichon urbicum & 1 & 14 & 13,359 & 27,500 & 40,873 & 4.89 \\
\hline Redwing Turdus iliacus & 2 & 108 & 9066 & 182,650 & 191,824 & 3.65 \\
\hline Eurasian Magpie Pica pica & 1 & 23 & 1551 & 61,110 & 62,684 & 0 \\
\hline Total & & 219,478 & $1,609,180$ & $6,431,862$ & $8,260,520$ & 22.26 \\
\hline
\end{tabular}


Second, to determine if ground-feeding was a trait of most predated birds, we characterized each species into Group 1: bird species rarely feeding on the ground, Group 2: bird species sometimes feeding on the ground, or Group 3: bird species frequently feeding on the ground (from Voous 1960, Yeatman-Berthelot \& Jarry 1991, Mullarney et al. 1999, Dubois et al. 2001). We used a Wilcoxon non-parametric test to compare pairs in each Group; it is assumed that there is no heterogeneity of variance in the samples (the absence of outliers and the very low dependence between observations has been verified).

Third, to assess the rate of Cat predation in comparison with other causes of mortality, we selected the following 10 categories that grouped different causes of death, selected from EURING and CRBPO databases: (1) shooting, (2) deliberate trapping (lime traps, glue traps and boxes to obtain song birds or bird meat), (3) involuntary trapping (crop-protection nets, drowning in artificial basins), (4) collisions with traffic (road, rail), (5) collisions with buildings (window panes, high-rise buildings), (6) predation by Cats, (7) predation of unknown origin/by other species, (8) natural causes (diseases, weather), (9) other causes and (10) causes unknown or undetermined. Here, we assessed the importance of Cat predation in comparison with the total of causes of mortality (in percentages).

\section{Results}

\section{BIRD SPECIES KILLED BY CATS}

Across the three programmes, the number of bird species killed by Cat predation was 83 . However, focusing on our 38 garden bird species (Table 1), we noted that, in Prog1, the 3 species most preyed upon by Cats were European Robin Erithacus rubecula, Dunnock Prunella modularis and Blackbird Turdus merula. The next most frequently predated upon species were mainly seed-eating birds: House Sparrow Passer domesticus, Eurasian Collared Dove Streptopelia decaocto, European Greenfinch Carduelis chloris and Goldfinch Carduelis carduelis.

In Prog2, mortality by Cats was the highest for European Greenfinch, Eurasian Siskin Carduelis spinus and Goldfinch. Blackbird, House Sparrow, European Starling Sturnus vulgaris, Dunnock, Eurasian Wren Troglodytes troglodytes and European Robin had the next highest rates of mortality from Cats. We noted that although they represented a very high proportion of ringed birds, the proportion of tits (Paridae) killed by Cats was moderate.

In Prog3, the most preyed upon species were European Greenfinch, European Robin and Blackbird.
The differences among the other species were minimal, and the distribution of predated species was more homogeneous. Based on the ranking process, several common species confirmed this trend, such as the Dunnock and Eurasian Collared Dove.

Overall (proportion of all returns on all the ringed birds of the three programmes), the most predated species were European Greenfinch, Eurasian Collared Dove and House Sparrow, which are three granivorous species. Comparing between bird species with different levels of ground-feeding showed that in the group of species that usually feeds or moves on the ground, Group 3, mortality rate by Cats was significantly higher (42 out of 10,000 ringed birds) than Group 2 (19 from 10,000) and Group 1 (12 from 10,000; Wilcoxon tests, both $P<0.0001)$.

\section{TEMPORAL CHANGES IN CAT PREDATION}

For each of the three programmes, an increasing trend in the proportion of birds killed by Cats was observed. For Prog1, we noted an average increase of $102 \%$ between 2007 and 2015. This increase was strong and significant (linear model, $r^{2}=0.674, d f=38, P=$ 0.015). For Prog2, the proportion of birds killed by Cats during 2000-2015 increased by $82 \%\left(r^{2}=0.597, d f=\right.$ 439, $P=0.022$ ). Data from Prog3 also showed an increasing trend in Cat predation, although at 52\% it was less strong $\left(r^{2}=0.422, d f=314, P=0.044\right)$. The analysis of the three datasets describes mortality caused by Cats as increasing over the last ten years.

\section{COMPARISON OF CAUSES OF DEATH}

The Prog1 data showed a preponderance of predation by Cats $(26.3 \%$ of the total, $n=146)$, followed by mortality due to collisions with window panes and buildings and then mortality from trapping, predominantly intentional trapping. Prog2 was distinguished by its very high incidence of mortality from shooting (39.6\%, $n=3439$ ), followed by predation by other species and by Domestic Cats. Mortality from shooting was very variable over time and was irregularly reported by observers. Prog3 showed a strong prevalence of mortality due to collisions with windows and buildings (25.7\%, $n=1933)$ followed by shooting and by mortality caused by Cats. The cause of predation by Cats always appeared as one of the three first causes of mortality in each programme (Table 2).

\section{Discussion}

\section{BIRD SPECIES KILLED BY CATS}

Our results demonstrate higher predation rates for ground dwelling birds, whether they are granivorous 
(House Sparrow, European Greenfinch and Eurasian Collared Dove) or insectivorous (European Robin, Blackbird and Dunnock). In addition, these species regularly visited bird feeders where they are more vulnerable (Dunn \& Tessaglia 1994). Mead (1982) showed an especially high recovery (31\%) of ringed Robins and Dunnocks in England. The population modelling study of Thomas et al. (2012) in the UK suggested that predation rates could significantly reduce the size of local bird populations for common urban species.

It appears that the habit of dwelling or visiting gardens is not the principal risk factor in terms of predation by Cats. The Eurasian Blue Tit Cyanistes caeruleus and Great Tit Parus major are abundant in urban areas rich in Cats, and they frequently visit bird feeders where they are predated on to a lower extent. Similarly, birds that are abundant in gardens, but which use mainly bushes and trees, such as Chiffchaff Phylloscopus collybita and Blackcap Sylvia atricapilla, were rarely predated on by Cats. Woods et al. (2003), despite using a different research method (prey brought by Cats into houses), also documented a strong representation of ground-foraging species such as House Sparrow and Blackbird, but they also cited tit species. Data given by different authors in different continents also underlined the important proportion of groundfeeding passerines in the diet of Cats (e.g. Baker et al. 2005, Blancher 2013).

\section{TEMPORAL CHANGE IN CAT PREDATION}

Cat predation on birds increased by 52 to $102 \%$ over the past 15 years. This increase appears connected with the parallel increase in the number of Cats in the two countries. Over the past 15 years (2000-2014), the number of house Cats grew from 9.67 to 12.7 million in France $(+30.1 \%$; FACCO 2017). Whereas between 2008 and 2014, they increased by 10\% in Belgium (SPF Economie 2016). We do not have information about the number and species of birds killed by feral Cats, which could have greatly increased over the same period in western European cities. However, feral Cats seem to remain a problem for cities since sterilization and capture programmes continue to be carried out by most municipalities: the feeding of feral Cats by city dwellers is still a common practise and kitten litters are often abandoned.

\section{COMPARISON OF THE CAUSES OF DEATH}

In each program, Cat predation appears as one of the three main causes of death in garden birds. Cat predation was a particularly strong factor in the programme dedicated to garden birds. In the USA, Loss et al. (2013) also reported the importance of predation by Cats; they extrapolated results and suggested that billions of birds were caught by Cats and hundreds of millions of birds were killed by collisions with buildings and vehicles. Collisions, mainly with windows, are unanimously recognized by ornithologists as a significant hazard for birds either living near inhabited areas or migrating (Machtans et al. 2013). Erickson et al. (2005) estimated that buildings, power lines and Cats were the causes of approximately $82 \%$ of the anthropogenic mortality of birds in the USA. To date, there has been a lack of data to identify house Cats as a factor in the decline of some bird populations throughout large areas. Moreover, Cat predation seems difficult to generalize across biotopes, regions or periods (Thomas et al. 2012, Krauze-Gryz et al. 2017). The decline of bird populations clearly involves numerous factors requiring new studies.

In fragile ecosystems such as urban areas, several solutions, more or less severe, have been proposed to reduce predation by Cats. For example, one solution is keeping house Cats indoors as much as possible (McDonald et al. 2015). Devices to reduce Cat predation on birds and other vertebrates are already available, and some have already been proven to be effective: colourful collars, making Cats more obvious to prey (Calver et al. 2007), collars emitting specific sounds (Clark \& Burton 1998) or belled collars (Ruxton et al. 2002). The issue of their acceptability by Cat owners and the possibility of developing them at a large scale remains unknown. Limiting Cats is another

Table 2. Causes of death of ringed birds according to the three ringing programmes (in percentage of dead birds found): Prog1 for wintering birds in French gardens, Prog2 for Programme STOC in France, and Prog3 for Belgian data.

\begin{tabular}{lccccccccc}
\hline & Shooting & $\begin{array}{c}\text { Deliberate } \\
\text { trapping }\end{array}$ & $\begin{array}{c}\text { Involuntary } \\
\text { trapping }\end{array}$ & $\begin{array}{c}\text { Collisions } \\
\text { with traffic }\end{array}$ & $\begin{array}{c}\text { Collisions } \\
\text { with buildings }\end{array}$ & $\begin{array}{c}\text { Predation } \\
\text { by Cats }\end{array}$ & $\begin{array}{c}\text { Predation by } \\
\text { other species }\end{array}$ & $\begin{array}{c}\text { Natural } \\
\text { causes }\end{array}$ & $\begin{array}{c}\text { Other } \\
\text { causes }\end{array}$ \\
\hline Prog1 & 1.26 & 21.08 & 1.98 & 8.65 & 21.62 & 26.31 & 12.79 & 6.13 \\
Prog2 & 39.64 & 7.85 & 1.90 & 5.92 & 8.94 & 12.76 & 14.85 & 8.07 & 0.18 \\
Prog3 & 18.59 & 17.60 & 1.43 & 8.96 & 25.67 & 16.31 & 5.62 & 3.88 & 1.93 \\
\hline
\end{tabular}


issue. An official programme targeting feral Cats is currently being developed in Belgium that includes systematic catching and sterilizing campaigns. In numerous French cities, Cats are also being controlled by mandatory individual identification and now systematic sterilization. This subject is not only a technical issue but also a social issue.

In conclusion, new research on cat populations and on the different aspects of its impact on biodiversity (especially in highly anthropized areas such as cities) needs to be developed. For example, we still know little about the health status of the birds killed by Cats and whether predation by Cats is additive or compensatory to natural mortality in birds.

We are grateful to Frédéric Jiguet, Pierre-Yves Henry and Olivier Dehorter from Centre de Recherche sur la Biologie des Populations d'Oiseaux (CRBPO) for their advice. Thank you also to the Belgian Ringing Scheme, the Royal Belgian Institute of Natural Sciences (Scientific Political SPP) and all the voluntary ringers who collected the data. We are grateful to the Region Ilede-France for supporting this project (AAP PICRI 110971).

\section{References}

Baker P.J. \& Harris S. 2007. Urban mammals: what does the future hold? An analysis of the factors affecting patterns of use of residential gardens in Great Britain. Mamm. Rev. 37: 297-315.

Baker P.J., Bentley A.J., Ansell R.J. \& Harris S. 2005. Impact of predation by domestic cats Felis catus in an urban area. Mamm. Rev. 35: 302-312.

Baker P.J., Molony S., Stone E., Cuthill I.C. \& Harris S. 2008. Cats about town: is predation by free-ranging pet cats (Felis catus) likely to affect urban bird populations? Ibis 150: 86-99.

Barratt D.G. 1997. Predation by house cats, Felis catus (L.), in Canberra, Australia. I: prey composition and preference. Wildl. Res. 24: 263-277.

Blancher P. 2013. Estimated number of birds killed by house cats (Felis catus) in Canada. Avian Conserv. Ecol. 8: 3. dx.doi.org/10.5751/ACE-00557-080203

Beckerman A.P., Boots M. \& Gaston K.J. 2007. Urban bird declines and the fear of cats. Animal Cons. 10: 320-325.

Bonnington C., Gaston K.J. \& Evans K.L. 2013. Fearing the feline: domestic cats reduce avian fecundity through traitmediated indirect effects that increase nest predation by other species. J Appl. Ecol. 50: 15-24.

Calver M., Thomas S., Bradley S. \& McCutcheon H. 2007. Reducing the rate of predation on wildlife by pet cats: the efficacy and practicability of collar-mounted pounce protectors. Biol. Cons. 137: 341-348.

Churcher P.B. \& Lawton J.H. 1987. Predation by domestic cats in an English village. J. Zool. 212: 439-455.

Coleman J.S., Temple, S.A. \& Craven S.R. 1997. Cats and wildlife: a conservation dilemma. University of WisconsinExtension.
Clark N.A. \& Burton N.H.K. 1998. A pilot field trial into the effectiveness of the CatAlert ${ }^{\mathrm{TM}}$ collar at reducing predation by domestic cats. BTO Research Report, British Trust for Ornithology, Thetford, UK.

Dauphiné N. \& Cooper R.J. 2009. Impacts of free-ranging domestic cats (Felis catus) on birds in the United States: a review of recent research with conservation and management recommendations. Proc. Fourth Int. Partners in Flight Conf.: Tundra to tropics, pp. 205-219.

Dowding J.E. \& Murphy E.C 2001. The impact of predation by introduced mammals on endemic shorebirds in New Zealand: a conservation perspective. Biol. Cons. 99: 47-64.

Dubois P.J., Le Marechal P., Olioso G. \& Yésou P. 2001. Inventaire des oiseaux de France. Nathan ed., Paris, France.

Dunn E.H. \&. Tessaglia D.L. 1994. Predation of birds at feeders in winter. J. Field Ornithol. 65: 8-16.

Erickson W.P., Johnson G.D. \& Young D.P. 2005. A summary and comparison of bird mortality from anthropogenic causes with an emphasis on collisions. USDA Forest Service General Technical Report PSWGTR 191: 1029-1042.

FACCO 2017. Les chiffres pour tout savoir sur le marché du petfood. www.facco.fr/les-chiffres

FEDIAF 2014. Nutritional guidelines for complete and complementary pet food for cats and dogs. Report from the European Pet Food Industry Federation.

Hagemeijer J.M. \& Blair M. 1997. The EBCC atlas of European breeding birds: their distribution and abundance. T. and A.D. Poyser, London.

Krauze-Gryz D., Żmihorski M. \& Gryz J. 2017. Annual variation in prey composition of domestic cats in rural and urban environment. Urban Ecosyst. 20: 945-952.

Loss S.R. \& Marra P.P. 2017. Population impacts of free-ranging domestic cats on mainland vertebrates. Front. Ecol. Environ. 15: 502-509.

Loss S.R., Will T. \& Marra P.P. 2013. The impact of free-ranging domestic cats on wildlife of the United States. Nat. Commun. 4: 1396. doi:10.1038/ncomms2380 (2012)

Machtans C.S., Wedeles C.H.R \& Bayne E.M. 2013. A first estimate for Canada of the number of birds killed by colliding with building windows. Avian Conserv. Ecol. 8: 6.

McDonald J.L., Maclean M., Evans M.R. \& Hodgson D.J. 2015. Reconciling actual and perceived rates of predation by domestic cats. Ecol. Evol. 5: 2745-2753.

Mead C.J. 1982. Ringed birds killed by cats. Mammal Rev. 12: 183-186.

Medina F.M., Bonnaud E., Vidal E., Tershy B.R., Zavaleta E.S., Donlan C.J., Keitt B.S., Le Corre M. \& Nogales M. 2011. A global review of the impacts of invasive cats on island endangered vertebrates. Global Change Biol. 17: 3503-3510.

Medway D.G. 2004. The land bird fauna of Stephens Island, New Zealand in the early 1890s, and the cause of its demise. Notornis 51: 201-211.

Mullarney T., Svensson L., Zetterstrom D. \& Grant P.J. 1999. The complete guide to the birds of Europe. Harper Collins ed., London.

Parmalee P. W. 1953. Food habits of the feral house cat in eastcentral Texas. J. Wildl. Manage. 17: 375-376.

Pellissier V., Cohen M., Boulay A. \& Clergeau P. 2012. Birds are also sensitive to landscape composition and configuration within the city centre. Landsc. Urban Plan. 104: 181-188. 
R Development Core Team 2016. R: A Language and Environment for Statistical Computing. R Foundation for Statistical Computing, Vienna, Austria.

Ruxton G.D., Thomas S. \& Wright J.W. 2002. Bells reduce predation of wildlife by domestic cats (Felis catus). J. Zool. 256: 81-83.

SPF Economie 2016. Statistics Belgium: Les ménages belges ont dépensé 1,3 milliard d'euros pour leurs animaux de compagnie en 2014. http://statbel.fgov.be/fr/statistiques

Thomas R.L., Fellowes M.D.E. \& Baker P.J. 2012. Spatiotemporal variation in predation by urban domestic cats (Felis catus) and the acceptability of possible management actions in the UK. PLoS ONE 7(11): e49369. doi.org/ 10.1371/journal.pone.0049369

Tschanz B., Hegglin D., Gloor S. \& Bontadina F. 2011. Hunters and non-hunters: skewed predation rate by domestic cats in a rural village. Eur. J. Wildl. Res. 57: 597-602.

Veitch C.R. 1985. Methods of eradicating feral cats from offshore island in New Zealand. In: Moors P.J. (ed.) Conservation of island birds. International Council for Bird Preservation, technical publications no. 3, Cambridge, pp. 125-141.

Voous K.H. 1960. Atlas of European birds. Nelson, New York, 1960.

Yeatman-Berthelot D. \& Jarry G. 1991. Atlas des oiseaux en hiver. Société Ornithologique de France, Paris.

Winter L. \& Wallace G.E. 2006. Impacts of feral and free-ranging cats on bird species of conservation concern: a five-state review of New York, New Jersey, Florida, California, and Hawaii. American Bird Conservancy, The Plains, VA.

Woods M., McDonald R.A. \& Harris S. 2003. Predation of wildlife by domestic cats Felis catus in Great Britain. Mammal Rev. 33: 174-188.

\section{Samenvatting}

Sinds de jaren zeventig is het aantal Huiskatten Felis silvestris catus in West-Europa toegenomen. Deze toename is vooral merkbaar in tuinen en parken in bewoond gebied, waar de huiskat lokaal de meest talrijke carnivoor is geworden. In het stedelijk gebied kan inzicht in het gedrag van katten belangrijk zijn voor het beheer van de biodiversiteit. In dit onderzoek hebben wij de predatie van katten op tuinvogels geanalyseerd met behulp van bestaande gegevens uit ringprogramma's in België en Frankrijk. Deze gegevens maken het mogelijk om (1) de door katten gedode vogelsoorten vast te stellen, (2) veranderingen in het aantal door katten gedode vogels te analyseren in de jaren 2000-2015 en (3) de doodsoorzaken, zoals gerapporteerd door waarnemers, te analyseren. De meest gepredeerde soorten waren zangvogels, zowel zaadetende als insectenetende (Roodborst Erithacus rubecula, Heggenmus Prunella modularis, Groenling Carduelis chloris), die vaak in de winter op de grond foerageren of voedertafels bezoeken. Vogels die niet op de grond foerageren (Tjiftjaf Phylloscopus collybita, Zwartkop Sylvia atricapilla) waren minder vertegenwoordigd. Grondgebonden gedrag was significant gecorreleerd met de mate van predatie. Tussen 2000 en 2015 nam de sterfte door kattenpredatie bij tuinvogels met minstens $50 \%$ toe, afhankelijk van het onderzochte ringprogramma. Dit viel samen met een groei van de kattenpopulaties. De sterfte door kattenpredatie is een van de belangrijkste doodsoorzaken blijkens de waarnemers $(12,8-26,3 \%$ van alle dode vogels), wat in dezelfde orde van grootte is als sterfte als gevolg van botsingen tegen ramen. Het resultaat van ons onderzoek benadrukt de noodzaak om de gevolgen van het mogelijke effect van katten voor het beheer van de stedelijke biodiversiteit in overweging te nemen, zowel op het niveau van tuinen als dat van steden in het algemeen. 